\title{
LANDASAN KEILMUAN KOMUNIKASI ISLAM
}

\author{
Daryanto Setiawan \\ Program Studi Komunikasi dan Penyiaran Islam STAI As-Sunnah Deli Serdang \\ Jl. Medan-Tg. Morawa, Km. 13 G. Darmo, Desa B. Sari, Kec. Tg. Morawa Kab. Deli Serdang \\ abu.syauqie82@gmail.com
}

\begin{abstract}
Abstrak: Judul tulisan ini adalah "Landasan Keilmuan Komunikasi Islam". Tulisan ini bertujuan untuk mengetahui apa saja yang menjadi landasan dalam ilmu komunikasi Islam. Metode yang digunakan dalam tulisan ini metode library research yang di ambil dari berbagai literartur yang mendukung dalam keilmuan komunikasi. Lahirnya ilmu komunikasi Islam tak lepas dari peran para pakar muslim dengan usaha-usaha yang telah mereka lakukan seperti menerbitkan bukubuku maupun jurnal yang berhubungan dengan komunikasi Islam.
\end{abstract}

Kata Kunci: Landasan, Ilmu Komunikasi, dan Islam

\section{Pendahuluan}

Komunikasi Islam merupakan bidang kajian baru yang lahir akibat falsafah, pendekatan teoritis dan penerapan ilmu komunikasi yang berasal dan dikembangkan di Barat dan Eropa yang tidak sepenuhnya sesuai dengan nilai dan budaya umat Islam.

Dengan usaha yang tidak mengenal lelah dan keseriusan yang tinggi dari para pakar Muslim yang meminati komunikasi Islam yang diantaranya dengan menulis dan menerbitkan berbagai karya berupa buku-buku maupun jurnal yang berhubungan dengan komunikasi Islam. Atas usahanya tersebut maka lahirlah ilmu komunikasi Islam.

Sebagai suatu ilmu yang masih dalam taraf pembenahan dan pengembangan, maka teori-teori yang digunakan pada permulaan ini dipinjam dan dimodifikasi dari teori-teori ilmu yang berbatasan dengan komunikasi Islam, terutama ilmu komunikasi umum sebagai induknya. Karena setiap ilmu yang baru muncul lazimnya menggunakan teori-teori dari ilmu yang berbatasan dengan ilmu yang berasangkutan. ${ }^{1}$

Komunikasi umum memandang bahwa komunikasi dan informasi merupakan barang komoditi yang dapat diperjual belikan. Dalam setiap aktivitas komunikasi, keuntungan yang paling besar diperoleh oleh pihak komunikator

\footnotetext{
${ }^{1}$ Syukur Kholil, Komunikasi Islami (Bandung: Ciptapustaka Media, 2007), h. 22.
} 
utama yang menguasai informasi. Setiap orang bebas mengeluarkan baik secara lisan maupun tulisan tanpa adanya hambatan dan pertimbangan pada nilai-nilai yang dianut oleh pihak lain. Dalam hal ini ideologi yang dianut adalah free flow of ideas by word and image, yang berarti bebas menyampaikan apa saja yang menarik tanpa mempertimbangkan nilai-nilai yang berlaku pada masyarakat. Sedangkan menurut perspektif komunikasi Islam, keuntungan paling besar penyampaian informasi berada pada pihak komunikator. Penyampaian sesuatu informasi pada hakikatnya bertujuan untuk mewujudkan kebahagiaan dan kemaslahatan individu atau masyarakat yang menjadi sasaran komunikasi. Disamping itu, kebebasan komunikasi harus dibarengi dengan rasa tanggung jawab serta dibatasi oleh nilai-nilai yang dianut oleh masyarakat, bangsa dan Negara. $^{2}$

Dari beberapa penjelasan diatas jelaslah bahwa persoalan mengenai keilmuan komunikasi Islam memang menarik dan layak untuk dikaji dengan tujuan untuk mencari dan membangun kerangkanya yang mapan.

\section{Komunikasi Islam Sebagai Ilmu}

Ilmu komunikasi merupakan salah satu ilmu pengetahuan sosial yang bersifat multidisipliner. Itu terjadi karena ilmu komunikasi berkembang melalui beberapa pendekatan. Pendekatan-pendekatan yang dipergunakan yang mempengaruhi peta ilmu komunikasi, berasal dari berbagai disiplin ilmu lain seperti psikologi, politik, lingusitik, antropologi dan lain sebagainya. ${ }^{3}$

Menurut Ujang Saefullah dalam bukunya Kapita Selekta Komunikasi Pendekatan Budaya dan Agama, dalam menelusuri landasan ilmiah komunikasi, tidaklah mudah, tetapi memerlukan kecerdikan dan ketekunan dalam mengkajinya. Oleh karena itu, para ahli komunikasi terbagi dalam dua paradigma pemahaman yang berbeda mengenai landasan ilmiah komunikasi, yaitu: (1) paradigma klasik, dan (2) paradigma kontemporer. Paradima klasik hampir satu abad yang lalu tetap bertahan pada keyakinan bahwa landasan ilmiah komunikasi terdiri dari filsafat, psikologi, sosiologi, dan antropologi. Sedangkan paradigma

\footnotetext{
${ }^{2}$ Ibid, h. 13-14.

${ }^{3}$ Muhammad Surip, Teori Komunikasi Perspektif Teoritis Teori Komunikasi (Medan: Unimed, 2011), h. 3.
} 
kontemporer, di samping mengakui temuan paradigma klasik, juga menemukan temuan baru bahwa landasan ilmiah komunikasi pun berasal dari matematika, fisika, dan biologi. ${ }^{4}$

Dari perspektif agama Islam, kita akan mengetahui bahwa Allah-lah yang mengajarkan kita berkomunikasi, dengan menggunakan akal dan kemampuan bahasa yang telah di anugerahkan kepada kita. Hal ini dinyatakan dalam al-Qur'an surat Ar-Rahman: 1-4 yang berbunyi :

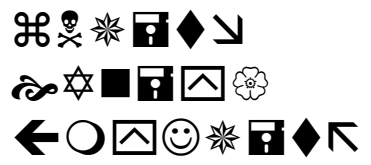

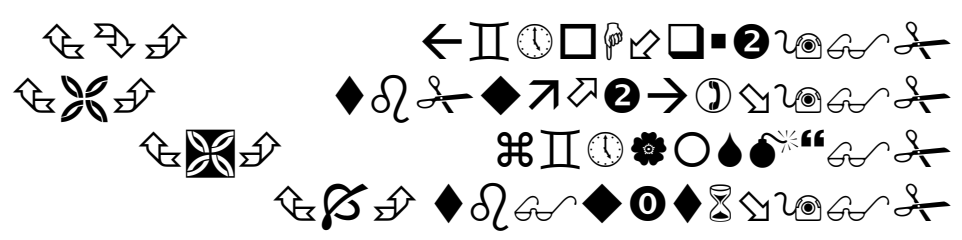

(Tuhan) yang Maha pemurah. Yang Telah mengajarkan Al Quran. Dia menciptakan manusia. Mengajarnya pandai berbicara. (Q.S. 55: 1-4)

Ayat-ayat al-Qur'an yang berhubungan dengan komunikasi sangat banyak. Selain ayat diatas setidaknya masih ada 53 Surah lagi yang berkaitan dengan komunikasi. $^{5}$

Selanjutnya, untuk memahami ilmu komunikasi Islam, hal pertama yang harus dipahami bersama adalah apakah komunikasi Islam itu suatu ilmu pengetahuan? Untuk menjawab pertanyaan tersebut maka langkah yang harus diketahui bersama adalah dengan mengetahui tentang pengertian ilmu dan pengertian pengetahuan.

Ilmu merupakan realitas logis, yang berarti dapat diterima oleh akal manusia. Hal ini dapat dipahami bahwa ilmu pada dasarnya adalah pengetahuan tentang sesuatu hal atau fenomena, baik yang menyangkut alam atau sosial (kehidupan masyarakat), yang diperoleh manusia melalui proses berfikir. Ciri suatu ilmu adalah memiliki metode. Metode berarti penyelidikan yang berlangsung menurut suatu rencana, dan sistematika rancangan tertentu. Jadi dapat dikatakan ilmu merupakan penyepadanan prosedur-prosedur yang dapat membimbing penelitian menurut arah tertentu. Sedangkan pengetahuan adalah kesan didalam pikiran manusia sebagai hasil penggunaan pancainderanya, yang

\footnotetext{
${ }^{4}$ Ujang Saefullah, Kapita Selekta Komunikasi Pendekatan Budaya dan Agama (Bandung: Simbiosa Rekatama Media, 2013), h. 11-12.

${ }^{5}$ Lihat buku Syukur Kholil “Komunikasi Islami” dari halaman 129 -187.
} 
berbeda sekali dengan kepercayaan (beliefs), takhyul (superstitions) dan penerangan-penerangan yang keliru (misinformations). ${ }^{6}$

Menurut Syukur Kholil dalam bukunya "Komunikasi Islami", secara umum pengetahuan dapat diartikan sebagai yang diketahui dan diperoleh dari pengalaman melalui proses berfikir yang tidak sistematis. Sedangkan ilmu adalah sesuatu yang diketahui melalui proses berfikir yang sistematis dan dilandasi dengan penelitian ilmiah. ${ }^{7}$

Sedangkan menurut Muhammad Surip dalam bukunya "Teori Komunikasi Perspektif Teoritis Teori Komunikasi" menyebutkan bahwa ilmu adalah pengetahuan tentang suatu bidang yang disusun secara bersistem menurut metode tertentu, yang dapat digunakan untuk menerangkan gejala tertentu di bidang (pengetahuan) itu. Pengetahuan adalah segala sesuatu yang diketahui; kepandaian. $^{8}$

Dikalangan ilmuwan ada keseragaman pendapat, bahwa ilmu selalu tersusun dari pengetahuan secara teratur, yang diperoleh dengan pangkal tumpuan (objek) tertentu dengan sistematis, metodis, rasional/logis, empiris, umum dan akumulatif. Pengertian pengetahuan sebagai istilah filsafat tidaklah sederhana karena bermacam-macam pandangan dan teori (epistemologi), di diantaranya pandangan Aristoteles, bahwa pengetahuan merupakan pengetahuan yang didapat di inderai dan dapat merangawsang budi. Menurut Descartes ilmu pengetahuan merupakan serba budi, oleh Bacon dan David Home diartikan sebagai pengalaman indera dan batin. Menurut Immanuel kant pengetahuan merupakan persatuan antara budi dan pengalaman, teori Phyrro mengatakan,, bahwa tidak ada kepastian dalam pengetahuan. Dari berbagai pandangan tentang pengetahuan diperoleh sumber-sumber pengetahuan berupa ide, kenyataan, kegiatan akal-budi, pengamlaman, sintetis budi, atau meragukan karena tak adanya sarana untuk mencapai pengetahuan yang pasti. $^{9}$ h. 34-35.

${ }^{6}$ Syukur Kholil, Teori Komunikasi Massa (Bandung: Ciptapustaka Media Perintis, 2011),

${ }^{7}$ Syukur Kholil, Komunikasi..., h. 18

${ }^{8}$ Muhammad Surip, Teori Komunikasi... h. 8

${ }^{9}$ M. Munandar Soelaeman, Ilmu Sosial Dasar Teori dan Konsep Ilmu Sosial (Bandung: PT Refika Aditama, 2011), h. 213. 
Dari beberapa pengertian ilmu dan pengetahuan diatas, maka dapat dikatakan bahwa antara ilmu dan pengetahuan terdapat perbedaan. Sedangkan permasalahan mengenai apakah komunikasi itu termasuk ilmu atau pengetahuan, sebenarnya para ahli sudah yang berkecimpung dalam ilmu pengetahuan sudah lama mempersalahkannya. Apabila komunikasi itu memang ilmu, maka komunikasi itu termasuk dalam ilmu apa. Apakah ilmu antropologi, ilmu sosial, ilmu alam, atau ilmu yang lain?

Untuk menjawab pertanyaan tersebut maka penulis akan menyebutkan ciri-ciri ilmu yang berdiri sendiri dan pengelompokan ilmu. Menurut Syukur Kholil dalam bukunya Komunikasi Islami, ciri-ciri suatu ilmu yang berdiri sendiri secara umum dapat dikemukakan sebagai berikut :

1. Bersifat Objektif. Setiap ilmu yang berdiri sendiri harus mempunyai objek; baik objek formal maupun objek material.

2. Bersifat empiris. Setiap ilmu harus dapat diuji kebenarannya dan dikembangkan dari waktu ke waktu di dunia pengalaman atau di dunia nyata yang dapat diamati dan dirasakan.

3. Bersifat sistematis, yaitu teratur dan tersusun berdasarkan hasil pembuktian ilmiah.

4. Bersifat rasional dan logis; sesuai dengan pemikiran yang dibangun berdasarkan logika.

5. Bersifat universal. Universal berarti bahwa kebenaran suatu ilmu itu harus berlaku umum, dan dapat diuji kebenarannya oleh siapa pun dan di mana pun. $^{10}$

Mengenai pengelompokan ilmu, disini penulis mengambil salah satu pendapat ahli ilmu yaitu H. Endang Saifuddin Anshari MA dalam bukunya, ilmu Filsat dan Agama, menggolongkan ilmu menjadi tiga kelompok, sama dengan penggolongan Stuart Chase dalam bukunya, The Proper Study of Mankind yakni:

a. Ilmu alam (natural science),

b. Ilmu sosial (social science),

c. humaniora, (studi humanitas, humanities science) ${ }^{11}$

\footnotetext{
${ }^{10}$ Syukur Kholil, Komunikasi..., h. 19.
} 
Adapun pengolompokkan ilmu selengkapnya adalah sebagai berikut:

a. Ilmu Pengetahuan Alam (Natural Science)

1) Biologi

2) Antropologi fisik

3) Ilmu kedokteran

4) Ilmu farmasi

5) Ilmu pertanian

6) Ilmu pasti

7) Ilmu alam

8) Ilmu teknik

9) Geologi

10) Dan sebagainya

b. Ilmu Kemasyarakatan (Social Science)

1) Ilmu hukum

2) Ilmu ekonomi

3) Ilmu jiwa sosial

4) Ilmu bumi sosial

5) Sosiologi

6) Antropologi budaya dan sosial

7) Ilmu sejarah

8) Ilmu politik

9) Ilmu pendidikan

10) Publistik dan jurnalistik

11) Dan sebagainya

c. Humaniora (Studi Humanitas, Humanities Science)

1) Ilmu agama

2) Ilmu filsagfat

3) Ilmu bahasa

4) Ilmu seni

5) Ilmu jiwa

6) Dan sebagainya ${ }^{12}$

Dari pengelompokkan ilmu diatas dapat diketahui bahwa komunikasi adalah ilmu bukan pengetahuan. Dari pengelompokan tersebut juga diketahui bahwa ilmu komunikasi termasuk dalam ilmu kemasyarakatan (social science).

Dalam perspektif Islam, ilmu khususnya yang berasal dari al-Qur'an banyak ayat-ayat yang menyebutkan tentang ilmu. Dengan penyebutan kata "alilm" dan derivasinya kata ilmu tersebut mencapai jumlah 823 kali. Bahkan dalam Hadis sendiri banyak hadis-hadis yang menyebutkan tentang keutamaan ilmu. Salah satu hadis yang menyebutkan tentang ilmu adalah:

11 Onong Uchjana Effendi, Ilmu Komunikasi Teori dan Praktek (Bandung, PT Remajarosdakarya, 2011) h. 1.

12 ibid, h. 2. 


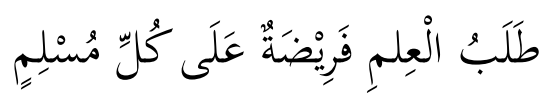

"Menuntut Ilmu adalah kewajiban setiap muslim" (HR. Ibnu Majah/224, dalam shahih al-Jaami'/3913).

Adapun pembagian ilmu dalam Islam sesuai yang dikemukakan oleh AlGhazali misalnya membagi ilmu dari aspek ghard (tujuan/kegunaan) pada syar'iyyah dan ghair syar'iyyah. Syar'iyyah yang dimaksudkan al - Ghazali adalah yang berasal dari Nabi Saw, sedangkan ghair syar'iyyah adalah yang dihasilkan oleh akal seperti ilmu hitung, dihasilkan oleh eksperimen seperti kedokteran, atau yang dihasilkan oleh pendengaran seperti ilmu bahasa. ${ }^{13}$

Oliver Leaman menjelaskan lebih lanjut, berdasar pada acuan al-Qur'an inilah maka kemudian ilmu pengetahuan dalam Islam ada dua jenis: 'Ilm yang mengungkap 'alam syahadah atau alam yang sudah diakrabi dan terpapar dalam sains alam; dan ma'rifah yang mendedahkan 'alam al-gha'ib atau alam yang tersembunyi dan karenanya lebih dari sekedar pengetahuan proposional (propositional knowledge). Cara memperoleh pengetahuan jenis kedua ini adalah wahyu. $^{14}$

\section{Aspek Ontologi Komunikasi Islam}

Istilah ontologi berasal dari bahasa Yunani yaitu "on" atau "ontos" artinya yang berada dan "logos" yang berarti ilmu pengetahuan atau ajaran. Dengan demikian secara etimologi, ontologi berarti ilmu pengetahuan atau ajaran tentang yang berada. Istilah ontologi dipopulerkan oleh Christian Wolff (1679-1714). Ontologi dipersamakan dengan istilah "metafisika". Para ahli yang mempersamakan ontologi dengan metafisika adalah Nicolai Hartmann seorang ahli ontologi dan Gottfried Martin di dalam bukunya Allgemein Metaphysic. ${ }^{15}$

Ontologi merupakan derajat pertama dalam suatu kajian keilmuan. Pada aspek ontologis ini pertanyaan-pertanyaan yang biasanya dipertanyakan adalah pertanyaan tentang pengertian ilmu dan objek suatu ilmu yang meliputi objek material dan objek formal.

\footnotetext{
${ }^{13}$ Adian Husaini, dkk, Filsafat Ilmu Perspektif Barat dan Islam (Jakarta: Gema Insani, 2013), h. 66.

${ }^{14}$ Ibid, h. 67.

${ }^{15}$ Sudarsono, Ilmu Filsafat: Suatu Pengantar (Jakarta: Rineka Cipta, 2001), h. 118.
} 
Mohd. Yusof Hussain et. Al. (1990:1) melalui buku Dua Puluh Lima Soal Jawab Mengenai Komunikasi Islam memberi definisi komunikasi Islam "sebagai proses menyampai atau bertukar perutusan dan maklumat dengan menggunakan prinsip dan kaedah komunikasi yang terdapat dalam al-Qur'an dan Hadith". Selain beliau, Mahyuddin Abd. Halim (1985: 43) menegaskan bahwa komunikasi Islam ialah "proses membekalkan khalayak dengan hakikat kebenaran agama Islam yang berteruskan bersandarkan kepada al-Qur'an dan al-Sunnah secara langsung atau tidak, melalui perantaraan media umum atau khusus, bertujuan membentuk pandangan umum yang betul berasaskan hakikat kebenaran agama yang memberi kesan kepada kehidupan seseorang dalam aspek akidah, ibadah dan muammalah". 16

Di dalam Kamus Besar Bahasa Indonesia pengertian obyek terdapat dalam 5 (lima) kategori. Pertama, obyek merupakan hal, perkara, atau orang yang menjadi pokok pembicaraan. Kedua, obyek diartikan sebagai benda, hal, dan sebagainya yang dijadikan sasaran untuk diteliti, diperhatikan, dan sebagainya. Ketiga, obyek digunakan pada nomina yang melengkapi transitif dalam klausa, misalnya "teh manis" dalam kalimat: "Kiki minum teh manis". Keempat, obyek berarti hal atau benda yang menjadi sasaran usaha sambilan, misalnya: "Berdagang kain menjadi salah satu obyek orang-orang di kota ini. Kelima, obyek merupakan titik atau himpunan yang bertindak sebagai sumber cahaya bagi suatu lensa, cermin, atau bagi suatu sistem lensa. ${ }^{17}$

Pada dasarnya, setiap ilmu memiliki dua macam obyek, yaitu obyek material dan obyek formal. ${ }^{18}$ Obyek material adalah benda atau hal yang menjadi obyek atau bidang ilmu. Ada juga yang memberikan batasan bahwa obyek material adalah seluruh lapangan atau bahan yang dijadikan obyek penyelidikan suatu ilmu. ${ }^{19}$ Sedangkan obyek formal adalah aspek atau sudut pandang suatu ilmu dalam melihat obyek ilmu, dan sebagainya. ${ }^{20}$

\footnotetext{
${ }^{16}$ Zulkiple Abd. Ghani, Islam, Komunikasi dan Teknologi Maklumat (Selangor: Dasar Cetak (M) SDN. BHD, 2001), h. 3.

17 Departemen Pendidikan dan Kebudayaan (Depdikbud), Kamus Besar Bahasa Indonesia (Jakarta: Balai Pustaka, 2001), h. 793.

${ }_{18}$ Amsal Bakhtiar, Filsafat Ilmu (Jakarta: RajaGrafindo Persada, 2005), h. 1

${ }^{19}$ Rizal Mustansyir \& Misnal Munir, Filsafat Ilmu (Pustaka Pelajar: 2001), h. 44.

${ }^{20}$ Depdikbud, Kamus Besar..., h. 793.
} 
Dengan mencermati pengertian atau pemahaman tentang obyek material sebagaimana di atas, maka yang menjadi obyek material ilmu komunikasi Islam adalah umat manusia secara keseluruhan. Maksudnya, sesuai tujuan komunikasi Islam bahwa bukan saja umat Islam (muslim) yang menjadi obyeknya, tetapi juga seluruh umat manusia (berarti termasuk di dalamnya non-muslim). Jadi, ilmu komunikasi Islam, sebagaimana juga ilmu komunikasi umum, membahas tentang manusia. $^{21}$

Menurut Syukur Kholil dalam bukunya "Komunikasi Islami" menyebutkan bahwa objek material komunikasi Islam itu adalah sama dengan objek material komunikasi umum, yaitu sama-sama manusia. Sedangkan objek formal atau sudut tertentu yang menjadi kajian komunikasi Islam ialah penyampaian pesan-pesan berdasarkan Alquran dan Hadis. Dalam hal ini komunikasi hanya membatasi diri dari pesan-pesan komunikasi berdasarkan Alquran dan Hadis. ${ }^{22}$

\section{Aspek Epistemologi Komunikasi Islam}

Epistemologi berarasal dari bahasa Yunani episteme yang berarti 'pengetahuan' (knowledge) dan logos yang berarti ‘ilmu. Epistemologi merupakan cabang filsafat yang membahas mengenai ilmu, sehingga epistemologi dikenal dengan nama filsafat ilmu atau teori ilmu. ${ }^{23}$

Epistemologi membahas secara mendalam segala sesuatu mengenai proses yang terlihat dalam usaha manusia untuk memperoleh ilmu. Ilmu merupakan pengetahuan yang didapat melalui metode keilmuan sehingga metode inilah yang membedakan ilmu dengan buah pemikiran lainnya. Menurut Richard Fumertton, pertanyaan-pertanyaan tentang epistemologi mencakup konsep ilmu, bukti, alasan untuk mempercayai, menjustifikasi, probabilitas atau kemungkinan, apa yang bisa dipercayai, dan konsep-konsep lainnya yang hanya dapat dipahami melalui satu atau beberapa hal tersebut diatas. Epistemologi bertujuan untuk menganalisa

\footnotetext{
${ }^{21}$ A. Muis, Komunikasi Islami (Bandung: Remaja Rosdakarya, 2001), h. 38.

${ }^{22}$ Syukur Kholil, Komunikasi..., h.

${ }^{23}$ Adian Husaini, dkk, Filsafat ..., h. 87.
} 
proses bagaimana mendapatkan ilmu. Oleh karena itu, pertama-tama harus diketahui di mana proses tersebut mulai dan kapan harus berakhir. ${ }^{24}$

Pada prinsipnya epistemologi adalah bagian filsafat yang membicarakan tentang terjadinya pengetahuan, sumber pengetahuan, asal mula pengetahuan, teori kebenaran, metode-metode ilmiah dan aliran-aliran teori pengetahuan. ${ }^{25}$ Dengan demikian, epistemologi dimaksudkan sebagai usaha untuk menafsir dan, di mana mungkin, membuktikan keyakinan kita bahwa kita mengetahui kenyataan yang lain dari diri sendiri. ${ }^{26}$

Sumber utama komunikasi Islam dari segi normatifnya ialah Alquran dan Hadis (wahyu). Namun sebagi suatu ilmu yang bersifat empriris, maka komunikasi Islam juga bersumber dari indera manusia. Komunikasi Islam juga bersifat logis, karena bersumber dari akal fikiran manusia. ${ }^{27}$

Dalam ilmu Komunikasi Islam yang menjadi sumber keilmuannya sebenarnya sama dengan ilmu-ilmu dalam perspektif Islam lainnya, yakni bahwa ilmu itu diperoleh dari Alquran dan Sunnah, penelaahan alam semesta, pengkajian terhadap diri manusia (anfus), dan penjelajahan terhadap tarikh (sejarah) umat manusia. Sedangkan alat untuk memperoleh ilmu komunikasi Islam adalah dengan mengoptimalkan fungsi inderawi dalam mempersepsi sumber, melalui pemahaman akal atau qalbu, dan melalui pengetahuan wahyu atau ilham. Hal ini berarti menunjukkan bahwa komunikasi Islam sesungguhnya mempunyai struktur keilmuan yang jelas dan konkrit sebagaimana halnya ilmu-ilmu lain. Jika ini bisa diterima, maka sebenarnya posisi ilmu komunikasi Islam berada pada wilayah tingkat kebenaran ilmu, bukan tingkat kebenaran agama. Oleh karena itu, Komunikasi Islam dapat dikatakan sebagai suatu disiplin ilmu. ${ }^{28}$

Komunikasi Islam sebagai hasil pemikiran ilmiah manusia hendaknya harus diuji tingkat kebenaran ilmunya. Dalam hal ini perlu adanya pendekatanpendekatan yang harus ditempuh untuk melihat bahwa Komunikasi Islam benar sebagai suatu disiplin ilmu. Komunikasi Islam dalam pengembangannya

${ }^{24}$ Ibid ..., h. 88.

${ }^{25}$ Dick Hartono, Kamus Populer Filsafat (Jakarta: Rajawali Press, 1986), h. 23.

${ }^{26}$ Kenneth T. Gallagher, Epistemologi Ilmu: Filsafat Pengetahuan (disadur oleh) P. Hardono Hadi (Yogyakarta: Kanisius, 1994), h. 53.

${ }^{27}$ Syukur Kholil, Komunikasi ..., h. 22.

28 http://manajemendakwah-iainsu-medan.blogspot.com/2010/05/epistemologi-komunikasi -islam. html. Diakses tanggal 21 Desember 2016. 
menggunakan metodologi ilmu-ilmu sosial. Sedangkan pendekatan-pendekatan yang digunakan dalam komunikasi Islam dapat bersifat positivis, interpretatif dan kritis.

Pendekatan positivis memandang pengetahuan sosial sebagai metode yang terorganisir untuk menggabungkan logika deduktif dan observasi empiris. Para peneliti positivis sering menggunakan data kuntitatif dan analisis statistik. Pendekatan interpretatif ialah analisis sistematis melalui obervasi rinci terhadap setting yang alami sehingga kepada pemahaman yang sebenarnya. Pendekatan interpretatif muncul sebagai oposisi terhadap aliran positivis. Sedangkan aliran kritis mendefinisikan ilmu pengetahuan sosial sebagai proses inquiri yang melebihi dari sekedar gambaan di permukaan saja untuk menyingkap struktur yang sesungguhnya dalam dunia materi. ${ }^{29}$

\section{Aspek Aksiologi Komunikasi Islam}

Kata aksiologi berasal dari bahasa Yunani; axios dan logos. Axios artinya nilai atau sesuatu yang berharga; sedangkan logos artinya akal, teori. Secara literal, aksiologi berarti teori nilai. Berbicara mengenai aksiologi berarti membicarakan tentang "nilai". Dengan demikian, aksiologi merupakan landasan filosofis bagi bangunan urutan nilai kegunaan ilmu komunikasi Islam dan merupakan salah satu unsur filosofis keilmuan yang bernilai sangat vital dalam membangun konstruksi ilmu komunikasi Islam. Aksiologi adalah asas mengenai cara bagaimana menggunakan ilmu pengetahuan yang secara epistemologis diperoleh dan disusun itu. ${ }^{30}$

Singkatnya aspek aksiologi komunikasi Islam ini berkaitan dengan penggunaan suatu ilmu yang bersumber dari al-Qur'an dan al-Hadis, yang mana ilmu tersebut memiliki kegunaan atau manfaat dan juga memiliki kontribusi yang baik bagi kepententingan umat manusia.

Menurut al-Attas (1995: 53-57), ilmu pengetahuan dikatakan bermanfaat apabila:

\footnotetext{
${ }^{29}$ Syukur Kholil, Komunikasi..., h. 22-23

30 http://manajemendakwah-iainsu-medan.blogspot.co.id/2010/05/aksiologi-kamunikasiislam.html. Diakases tanggal 21 Desember 2016.
} 
1. Dapat mendekatkan seseorang kepada kebenaran Allah SWT.

2. Dapat membantu umat dalam mengaktualisasikan tujuannya.

3. Dapat memberi pedoman bagi semua manusia.

4. Dapat memberikan solusi terhadap pemecahan masalah hidup manusia. $^{31}$

Dalam Islam, tujuan utama dari ilmu adalah untuk mengenal Allah swt, dan meraih kebahagiaan ( $\left.s a^{\prime} a d a h\right)$, sebab ilmu mengkaji tentang "ayat-ayat" (tanda-tanda) - baik ayat kauni atau qauli - yang menjadi petunjuk bagi yang ditandai, yaitu Allah Sang Pencipta. ${ }^{32}$

Pada aspek penggunaan, komunikasi Islam juga memberi manfaat yang besar bagi kehidupan umat manusia. Manfaat itu antara lain dapat dikemukakan sebagai berikut:

1. Dapat mendekatkan manusia kepada kebenaran ilahi, sehingga mereka mendapatkan kebenaran yang hakiki.

2. Membantu manusia dalam mengaktualisasikan diri untuk kehidupan yang lebih baik.

3. Memberi solusi terhadap berbagai persoalan hidup manusia.

4. Menciptakan kedamaian hidup manusia.

5. Dan sebagainya. ${ }^{33}$

\section{Kesimpulan}

Berdasarkan uraian-uraian diatas mengenai landasan keilmuan komunikasi Islam dapat disimpulkan sebagai berikut :

1. Ilmu adalah sesuatu yang diketahui melalui proses berfikir yang sistematis dan dilandasi dengan penelitian ilmiah. Sedangkan pengetahuan dapat diartikan sebagai yang diketahui dan diperoleh dari pengalaman melalui proses berfikir yang tidak sistematis

2. Dari beberapa penggolongan dan pengelompokan tentang ilmu dapat diketahui bahwa ilmu komunikasi termasuk dalam pengelompokan ilmu sosial dan merupakan ilmu terapan.

\footnotetext{
${ }^{31}$ Syukur Kholil, Komunikasi..., h. 23

${ }^{32}$ Adian Husaini, dkk, Filsafat ..., h. 32

${ }^{33}$ Syukur Kholil, Komunikasi..., h. 24
} 
3. Ilmu komunikasi juga merupakan ilmu yang bersifat multidisipliner, karena objek materialnya sama dengan ilmu-ilmu lain terutama yang termasuk kedalam ilmu sosial.

4. Berdasarkan uraian tentang landasan keilmuan komunikasi Islam dilihaı dari aspek ontologi, epistemologi, dan aksiologi diatas, maka komunikasi Islam dapat disebut sebagai salah satu cabang ilmu komunikasi.

\section{Pustaka Acuan}

Alquran Alkarim

Bakhtiar, Amsal. Filsafat Ilmu. Jakarta: RajaGrafindo Persada, 2005.

Departemen Pendidikan dan Kebudayaan (Depdikbud). Kamus Besar Bahasa Indonesia. Jakarta: Balai Pustaka, 2001.

Effendi, Onong Uchjana. Ilmu Komunikasi Teori dan Praktek. Bandung: PT Remajarosdakarya, 2011.

Ghani, Zulkiple Abd. Islam, Komunikasi dan Teknologi Maklumat. Selangor: Dasar Cetak (M) SDN. BHD, 2001.

Hartono, Dick. Kamus Populer Filsafat. Jakarta: Rajawali Press, 1986.

Husaini, Adian dkk. Filsafat Ilmu Perspektif Barat dan Islam. Jakarta: Gema Insani, 2013.

Kholil, Syukur (ed). Teori Komunikasi Massa. Bandung: Ciptapustaka Media Perintis, 2011.

Kholil, Syukur. Komunikasi Islami. Bandung: Ciptapustaka Media, 2007.

Muis, A. Komunikasi Islami. Bandung: Remaja Rosdakarya, 2001.

Mustansyir, Rizal dan Misnal Munir. Filsafat Ilmu. Pustaka Pelajar, 2001.

Saefullah, Ujang. Kapita Selekta Komunikasi Pendekatan Budaya dan Agama. Bandung: Simbiosa Rekatama Media, 2013.

Soelaeman, M. Munandar. Ilmu Sosial Dasar Teori dan Konsep Ilmu Sosial. Bandung: PT Refika Aditama, 2011.

Sudarsono, Ilmu Filsafat: Suatu Pengantar. Jakarta: Rineka Cipta, 2001.

Surip, Muhammad. Teori Komunikasi Perspektif Teoritis Teori Komunikasi. Medan: Unimed, 2011. 
T. Gallagher, Kenneth. Epistemologi Ilmu: Filsafat Pengetahuan (disadur oleh) P. Hardono Hadi. Yogyakarta: Kanisius, 1994.

http://manajemendakwah-iainsu-medan.blogspot.com/2010/05/epistemologikomunikasi-islam.html. Diakses tanggal 21 Desember 2016.

http://manajemendakwah-iainsu-medan.blogspot.co.id/2010/05/aksiologikamunikasi-islam.html. Diakses tanggal 21 Desember 2016. 